\title{
Transforming the European Asylum Support Office into the European Union Agency for Asvlum
}

\author{
David FER\ÍNDEZz-ROJO**
}

\begin{abstract}
1bstract: From May to July 2016, the European Commission put forward a wide-ranging European Asylum package, which included the establishment of a European Union Ageney for Ass lum with the aim of ensuring that Vember States get more operational assistance in processing ass lum applications. This article analyzes the key operational novelties that the proposed transformation of the European Asv lum Support Office into the European Union Agency for Ass lum will bring.
\end{abstract}

Kevwords: European Asvlum Support Office, EASO, European Union Agenev for Asvlum, EU agencies.

\section{(1) INTROOUC CTIO)}

In 2009, the European Commission proposed the creation of the European Asylum Support Office (E ASO)' and in May 2010 Regulation No 139 2010, establishing E ISO, was introduced. In June 20rt, the Office was officially inaugurated in Malta, where its seat is located, ${ }^{2}$ with the mission of strengthening mutual trust and the operational cooperation between the competent national asy lum authorities in order to 'increase convergence and ensure ongoing quality of Member States' decision-making procedures'.3 That is, E ASO was designed to assist the Member States in coherently applying the existing asylum acquis and guaranteeing the effective implementation of all the legislative and operational measures. Itowever, the ageney was not delegated direct or indirect powers in relation to the taking of decisions (...) on individual applications for international protection? ${ }^{\prime}$ The relationship between the Member States and E ASO is one of mutual dependency. E ASO's operational assistance may enhance the capacity of the Member States to effectively implement the European asylum framework, provided that they contribute sufficient human and material resources that allow the agency to fully develop its operational goals and

a Irlicle published on.31 December 2org

Assistant Professor, Universitv of Deusto. Mail: davidfrojo a deusto.es. This article was written within the context of the research project 'The European Union's policies on asylum: confluences between the internal and the external dimensions' (DER-2017-82/66-R), funded by the Spanish Ministry of Economy and Competitiveness and FEDER, as well as the Jean Monnet Chair EU Economic and Legal Integration for People, E AC Ao3 2016 (2017-2020).

Proposal for a Regulation of the European Parliament and of the Council establishing a European Asylum Support Office, COM (2009) 66 final, 18.02 .2009 .

2 Seat Igreement Between the Government of Malta and the European Asvlum Support Office, 24.05.2011.

3 Regulation (EU) Do 1392010 of the European Parliament and of the Council of rg May 20 o establishing a European Asslum Support Office, O.J L-132, recital $\underset{y}{ }$.

个 Ibid., recital ${ }_{1 / 4}$. 
conduct its activities. The actual impact of E ASO thus depends on 'the Member States' willingness to use the possibilities it offers and, on their commitment, to engage in such collaboration?.

Due to the unprecedented wave of asy lum applications since 2015 as a consequence of the so-called 'refugee crisis', the national asy lum and reception systems were overburdened, increasingly requesting the assistance of E ASO on the ground. ${ }^{6}$ From May to July 2016, the European Commission put forward a wide-ranging European asylum package, which included the establishment of a European Union Agency for Asylum (EU N 1). Subsequently, President Juncker announced in his speech on the 2018 State of the Union made on 12 September, the Commission's intention to 'further develop the European Asylum Agency to make sure that Member States get more European support in processing asylum seekers in line with the Geneva Convention. ${ }^{8}$ On the same dav, the Commission, welcoming the agreement concluded by the legislators, released an amended proposal containing only targeted amendments reinforcing the operational tasks of the EU $\triangle{ }^{9}{ }^{9}$

While the Council and the European Parliament reached a partial agreement on 28 June 2017 on twelve chapters of the Regulation on the future EU 1 I with the exception of Chapter I (The European U nion Agency for Asylumi), Chapter 3 ('Country information and guidance'), Chapter 5 ('Monitoring'), and Chapter 9 ('Organization of the Agency')," an overall agreement will only be possible once the linkages with the other legislative proposals in the Common European Isylum System (CE IS) package have been resolved'." The final adoption of the new EU I I Regulation will not take place until the whole asy lum package is finalized.

\footnotetext{
5 Commission, Enhanced intra-EU solidarity in the field of asylum: An EU agenda for better responsibility-sharing and more mutual trust', COM (2011) 835 final, $02.12 .2011,3$.

6. Commission, 'Towards a Reform of the Common European Asylum System and Enhancing Legal Avenues to Europe', COM(2016) 197 final, o6.o/.2016, 12. See, E. Guild, et. al., 'Rethinking asvium distribution in the EU: Shall we start with the facts?', CEPS Commenlary, 17.06.2016, 1-9.

7 Commission, 'Proposal for a Regulation of the European Parliament and of the Council on the European Union Agency for Asylum and repealing Regulation (EU) \o 439 2010, COM (2016) 27 I final, 0/.0.2016.

8 Commission, 'State of the Union 2018 the Hour of European Sovereignt?', 12.09.2018.

9 Amended proposal for a Regulation of the European Parliament and of the Council on the European Union Agency for Asylum and repealing Regulation (EU) \o 4392010, COM (2018) 633 final, 12.09.2018.

") Council, 'Proposal for a Regulation of the European Parliament and of the Council on the European Union Agency for Asylum and repealing Regulation (EU) No 1392010 - State of play and guidance for further work', doc. 105.j5/17, 27.06.2017. Public access was requested to the Council to the note of / December 2017 from the Presidency to the Permanent on the European Union Agency for Asylum (doc. $1 / 998$ 17) but such access was denied since the note gives details of the on-going discussion and identifies sensitive issues that need to be addressed before the Council can reach an agreement. Release to the public of the information contained in this document would affect the negotiating process and diminish the chances of the Council reaching an agreement as it may put delegations under additional pressure of stakeholders'. In this regard see, Appendix A: "public access to documents'.

"Council Press Release, 'EU Agency for Asylum: Presidency and European Parliament reach a broad political agreement', $43^{1 / 17}$, 29.06.2017. See, Council, 'Reform of the Common European Asylum System and Resettlement', doc. 15057 1 17, o6.12.2017, 6. For instance, the cross-references between the future Dublin Regulation and the EU A $\mathrm{A}$ are constant. Specifically, article 49 Proposal for a Regulation establishing the criteria and mechanisms for determining the Member State responsible for examining an application for international protection lodged in one of the Member States by a third-country national or a stateless person (recast) (COM(2016) 270 final, o/.05.2016) states that the European Union Agency for Asylum shall set up and facilitate the activities of a network of the competent authorities referred to in Article 47 (I), with a view to enhancing practical cooperation and information sharing on all matters related to the application of this Regulation, including the development of practical tools and guidance'.
} 
Hence, this article analyzes the key operational novelties tabled in both 2016 and 2018 European Commission proposals, and critically assesses what changes the will bring about to E ISO's current mandate in comparison with the mandate of the European Border and Coast Guard (EBCG) following Regulation 2016/162/4 of I/4 September $2016 . .^{12}$

\section{(B) THEEUNIS MONITORISGROLE}

While the EU $\triangle 1$ is not mandated to set out a comprehensive strategy of asylum, the agency should guide the Member States on the situation in third countries of origin and 'ensure greater convergence and address disparities in the assessment of applications for international protection'. ${ }^{3}$ The EU I I will 'develop a common analysis on the situation in specific countries of origin and guidance notes to assist Member States in the assessment of relevant applications' (article ro(t) partial agreement on the EU A A). Importantly, as soon as the EU I I's Management Board endorses the guidance notes, the Member States should take them into account when examining applications for international protection, without prejudice to their competence for deciding on individual applications (article so (2a) partial agreement on the EUAI).

The new monitoring role of the EU $\mathbf{\text { I }}$ will also indirectly contribute to shape a common strategy of asylum in the European Union (EU). A key difference between E ASO and the future EU A I will be its monitoring role in order to guarantee that the national authorities are sufficiently prepared to manage exceptional and sudden pressure in their asylum system. Should the EU A Y's information analy sis raise serious concerns regarding the functioning or preparedness of a Member State's asylum or reception systems, the agency, on its own initiative or at the request of the European Commission, may initiate a monitoring exercise (article 1/(2) partial agreement EU \ \).

The Member State concerned will receive the findings of the monitoring exercise and the draft recommendations of the EUA A's Executive Director on the basis of which it should provide for comments. Taking Member State's comments into account, the EU A Y's Management Board will, by a decision of wo-thirds of its members, adopt those recommendations (article 1/(3a) partial agreement EU A \). As with the EBCG's vulnerability assessments (article ${ }_{3}$ Regulation 2016/162/), the future EU A will be conferred a recommendatory power in order to put forward measures to be adopted by the national authorities. Nevertheless, Member States will still maintain indirect control of the EUAM's

${ }_{12}$ Regulation (EU) 2016/162/ of the European Parliament and of the Council of 1/4 September 2016 on the European Border and Coast Guard, OJ L-2ృ. In this regard see, P. De Bruycker, The European Border and Coast Guard: A Vew Model

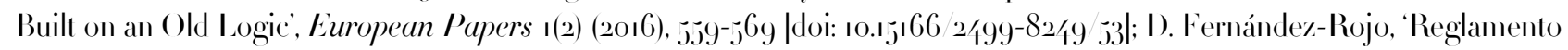

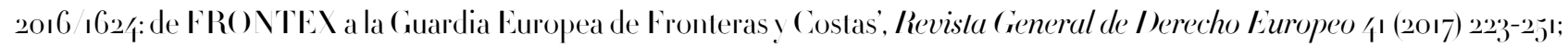
S. Carrera, et. al., 'A European Border and Coasl Guard: Whal's in a Name?', CEPS Paper in Liberly and Securily in Europe, 88 (2016) 1-22; J. Santos Vara, 'La transformación de FRO \TEX en la Agencia Europea de la Guardia de Fronteras y Costas: ¿hacia una centralización en la gestión de las fronteras?', Revisla de Derecho Comunilario Europeo 59 (2018) 1/33-186 |doi: htlps: / doi.org 10.180/2 cepe rdce.j9.0/1.

13 Commission, Proposal for a on the European Union Ageney for Asylum, COM (2016) 27 final, o/4.05.2016, 7 . 
recommendations through the enhanced majority that is required in the Management Board.'1

Whereas the Commission did not initially propose that the EU A Y's Execulive Director should be able to appoint experts from the staff of the agency to be deployed as liaison officers in Member States, the provisional text agreed on 28 . June 2017 indicates that liaison officers shall foster cooperation and dialogue between the Agency and the Member States' authorities responsible for asylum and immigration and other relevant services' (article s/a(3) partial agreement EU A U). Like the EBCG's liaison officers, they will facilitate the monitoring role of the agency by reporting regularly to the Execulive Director on the situation of asylum in the Member States and their capacity to manage their asylum and reception systems effectively (article s/a (3) partial agreement EU A 1).

The EU A I will thus be in charge of monitoring the operational and technical application of the CEAS in order to prevent or identify possible shorteomings in the asylum and reception systems of Member States and to assess their capacity and preparedness to manage situations of disproportionate pressure so as to enhance the efficiency of those sy stems' (article 13(1) partial agreement EU A A). With this aim, the agency will namely assess the national procedures for international protection, staff available and reception conditions (i.e. infrastructure, equipment or financial resources) on the basis of the information provided by the Member State concerned and by relevant intergovernmental organizations or bodies, as well as by means of analy sis on the situation of asylum and on-site visits that the agency may undertake (article 13 (3) and (4) partial agreement EU A X). This new monitoring task of the EU A 1 could ultimately contribute to the effective and harmonized implementation of the CE AS by the Member States.'s

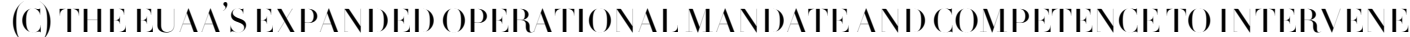

The EU 1 I will be in charge of organizing and coordinating the appropriate operational support at the request of the Member States or upon the initiative of the agency in cases where the national asylum and reception sy stems are subject to exceptional pressure. The operational role of the EU A I will specifically consist in: I) assisting Member States in receiving and registering applications for international protection; 2) facilitating the examination of applications for international protection; 3) advising, assisting or coordinating the set up or the provision of reception facilities by the Member States; f) forming part of the migration management support teams at hotspot areas; j) supporting Member States in identifying applicants in need of special procedural guarantees, applicants with special reception needs, or other persons in a vulnerable situation, as well as in referring those persons to the competent national authorities

'1/ See, L. Tsourdi, 'Monitoring and Steering through FRO NTEX and E ISO 2.0: The Rise of a Vew Model of MFSJ agencies?", EU Immigralion and 1sylum Law and Policy Blog, 29.01.2018; A. Ripoll Servent, 'A new form of delegation in EU asslum: Agencies as proxies of strong regulators', Journal of Common Warkel Studies j6(1) (2018) 83-100.

is See, L NIICR, 'Comments on the European Commission proposal for a Regulation of the European Parliament and of the Council on the European Union Agenes for Asvlum - COM (2016) 271', December 2016, 13-1/4 and ECRE, 'Comments on the Commission Proposal for a Regulation on the European Union Agency for Asslum and repealing Regulation (EU) Vo 1392010 COM(2016) 27i', July $2016,11-1$ /. 
for appropriate assistance; and 6) deploying ASTs and technical equipment (article I6(2) partial agreement EUA ).

Following the lead of the EBCG's Rapid Reaction Pool, an asy lum reserve pool of a minimum of joo persons should be made available by the Member States for their immediate deployment and should assist those national authorities subject to extraordinary migratory pressure (article ig \ (6) partial agreement EU A ). As article 25 Regulation 2016/162/ on the EBCG provides, the EU A I's Executive Director may suspend or terminate the deployment of the Asylum Support Teams (AST) if the conditions to carry out the operational and technical measures are no longer fulfilled, the operational plan is not respected, or

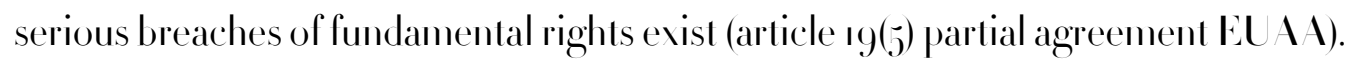

Since the future EU A I will deploy experts from its own staff to form part of the AST, with the goal of reducing the dependence of the agency on the technical equipment of the Member States, the EU $\triangle$ I may also deploy its own equipment to the host Member State insofar as this may complement equipment already made available by the host Member State or other EU agencies (article 23 (I) partial agreement EU A A). It remains to be seen whether the future agency will be allocated sufficient resources to purchase, lease, or effectively manage its own equipment.

Moreover, the future Regulation on the EU 11 details the functions of the agency in the recently established hotspots." Upon the request of a Member State facing an exceptional and sudden migratory pressure, the EUA X's Executive Director should draw up a comprehensive reinforcement package consisting of various activities coordinated by the relevant Union agencies, and deploy AST as part of migration management support teams (article 21 (I) partial agreement EU X). In 2018, the European Commission proposed to further expand, upon the request of a concerned Member State, the scope for the use of the migration management support teams to any situation and not necessarily limited to circumstances of extraordinary migratory pressure.

Another important novelty that the EU A I will bring is the possibility of making an emergency intervention. According to the European Commission's proposal, the EU A 1 may make an emergency intervention if the functioning of the CE IS is jeopardized due to: the insufficient action of a Member State in addressing the disproportionate pressure on the asylum and reception systems in such State (article 22(t) partial agreement EU \), the refusal of the competent national authorities to request or accept assistance from the EU \ 1 (article 22(I) partial agreement EU \ \), or the unwillingness of a Member State to comply with the Commission's recommendations to implement an action plan intended to address serious shortcomings identified during a monitoring assessment (article s/(3a) partial agreement EU A I).

16 See, F. Casolari, 'The EU's hotspot approach to managing the migration crisis: a blind spot for international responsibility?', The Ilalian Yearbook of Inlernalional Law Online 2ృ(1) (2016) 109-13价 D. Fernández-Rojo, 'Los hotspots: expansión de las tareas operativas y cooperación multilateral de las agencias europeas Frontex, Easo y Europol', Revisla de Derecho Comunilario Europeo 61 (2018) 1013-1056, |10OI: h11ps:/doi.org 10.180/2/cepe/rdce.61.o6|; S. Horii, "Accountability, Dependency, and EU Agencies: The IIotspot Approach in the Refugee Crisis', Refugee Surver Quarlerly (2018) 1-27, |DOOI: hllps: doi.org 10.1093 rsq hdvooj.. 
As was the case with the adoption of the EBCG, some Member States expressed their opposition to indirectly bestowing 'intervention powers' upon the future EU $\triangle$ \.77

The procedure set out in article 19(1) Regulation 2016/162/4 of the EBCG, regarding situations at the external borders requiring an intervention, will to a more limited extent, be replicated for the EU A I. While the proposal for a Regulation on the EU 14 originally stated that the Commission would be the EU institution in charge of adopting a decision by means of an implementing act to support the Member State concerned, the EU A A's provisional text states that the Council shall be the authority responsible for adopting such an implementing act. Three days after the Council adopts its implementing act, the EU I I's Executive Director should draw up an Operational Plan and determine the details of the practical implementation of the Council decision (article 22(2) partial agreement EUA D). Subsequently, the Member State concerned will have three days to reach an agreement with the Executive Director on the Operational Plan and should immediately cooperate with the agency to facilitate the practical execution of the measures put forward (article 22(4) partial agreement EU \ 1). The future Regulation of the EU A does not include a similar provision like article $19(10)$ Regulation 2016/162\%, which indicates that if a Member State neither executes the decision adopted by the Council, nor agrees with the EBCG's Director Operational Plan within 3 o days, the European Commission may authorize the re-establishment of border controls in the Schengen area.

\section{(D) THE EU IISROLEIXEXIMINIXG ISILUM IPPLICATIOXS}

Another novelty in comparison to the E ASO will be the involvement of the EU A 1 in the examination of international protection applications. Several provisions of the EU 1 I mention that the ageney will assist or facilitate the Member States in examining the applications of international protection submilted to their asylum systems. Alongside the operational and technical assistance that the EU A I should provide to Member States upon their request, the agency will facilitate the examination of applications for international protection (article I6(2)(b) partial agreement EU A S) submitted to the competent national authorities. In this regard, the AST should support Member States with operational and technical measures, including (...) by knowledge of the handling and management of asylum cases, as well as by assisting national authorities competent for the examination of applications for international protection and by assisting with relocation or transfer of applicants or beneficiaries of international protection' (recital $\mathbf{6}$ partial agreement EU $\mathbf{\text { U) }}$.

The European Commission's proposal tabled on September 2018 mainly centers on expanding the EU A A's role in the administrative procedure for international protection. Specifically, the new article ifa

17 Senate of the Parliament of the Czech Republic, $10^{\text {th }}$ Term $5^{15^{\text {th }}}$ Resolution of the Senate Delivered on the $27^{\text {th }}$ session held on $21^{\text {th }}$ August 2016 on the Proposal for a Regulation of the European Parliament and of the Council on the European Union Agency for Asylum and repealing Regulation (EU) Xo 4392010 and Opinion of the Foreign and European Union Affairs Committee of the Senate of the Republic of Poland on the Proposal for a Regulation of the European Parliament and of the Council on the European Union Agency for Asslum repealing Regulation (EU) No 139 20ro COM(2016)27r adopted at the meeting of 28 September 2016 . 
states that the EU A I's AST should, among other measures, identify any needs for special procedural guarantees, carry out the admissibility and substantive interview, assess the evidence, and prepare decisions on applications for international protection. This means that, upon the request of a Member State, the future EU 1 I will be able to draft decisions on asylum applications. However, the text of the Regulation highlights that the decisions on individual applications for asylum remain the Member States' sole responsibility (article ı6a). In addition, recital q $^{6}$ of the $2018 \mathrm{Commission}$ proposal repeats that 'the competence to take decisions by Member States' asylum authorities on individual applications for international protection remains with Member States'. Hence, the Commission, both in 2016 and 2018 , clearly establishes that the future EU A 1 cannot be conferred decision-making powers. The question to be answered is whether the EU $\mathbf{~}$ I will be able to jointly process applications for international protection, and if it cannot, to what extent the agency may support the processing of asylum applications.

In 2013, the Commission adopted a study in which the concept of "joint processing' was defined as 'an arrangement under which all asylum claims within the EU are processed jointly by an EU authority assuming responsibility for both preparation and decision on all cases, as well as subsequent distribution of recognized beneficiaries of international protection and return of those not in need of protection'. ${ }^{8}$ This study tabled four options that progressively move from supporting the Member States in processing asylum applications through an agency such as EASO EU A \, to designing a centralized EU authority with decision-making powers and responsible for all asylum processing.

Currently, the Member States remain exclusively competent to adopt decisions concerning the admissibility and applications for international protection. The next level of European integration would entail the introduction of a mechanism of joint processing in situations where a Member State is subject to an extraordinary number of asylum applications. Joint processing teams of E ASO would be deployed and make recommendations on asylum cases to the requesting Member State, which would continue to have exclusive decision-making powers.

The AST of E ASO deployed in the Greek hotspots are in practice already adopting recommendations on the admissibility of the international protection applications. The Greek Asylum Service's officials when adopting a decision in fact largely accept these recommendations. ${ }^{99}$ Precisely, the future EU A I, upon the request of a concerned Member State, will formally be conferred the power to facilitate the examination of applications for international protection. Actually, the envisaged EEU A Regulation

\footnotetext{
18 Commission, 'Study on the Feasibility and legal and practical implications of establishing a mechanism for the joint processing of asylum applications on the territory of the EU, 13.02.2013 at 11 .

19 Greece Refugee Rights Initiative, E ISO's Operation on the Greek Ilotspots An overlooked consequence of the EUTurker Deal', March 2018; European Center for Constitutional and Iluman Rights, 'E ISO's influence on inadmissibility decisions exceeds the agency's competence and disregards fundamental rights', April 20r7; E. Tsourdi, 'Bottom-up salvation?; from practical cooperation towards joint implementation through the European Asylum Support Office', European Papers I

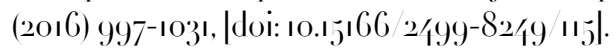


provides a legal basis to the practice that the E $\mathrm{XSO}$ has already developed in Greece as acknowledged by the European Onbudsman in its decision on a complaint about E ISO's role in that Member State.20

However, the future EU 14 will be far from deciding, in first inslance and in appeal, every asylum application within the EU. Instead, the European Commission has opted to reinforee the operational tasks of E ISO and maintain the Member States as the exclusive decision-making authorities. Centralizing the asylum decision-making process would ensure a full harmonization of the national procedures and foster a consistent evaluation of protection needs. Nevertheless, this option demands a major institutional transformation' and 'substantial resources' that can only be envisioned in the long-term. ${ }^{22}$

Moreover, there are doubts as to whether article $78(2)$ Treaty on the Functioning of the EU (TFEU) is a sufficient legal basis for conferring the power to exclusively adopt binding decisions on all asvlum claims to a EU authority. Pursuant article $78(2)$ TFEU, the EU shall ensure: '(...) common procedures for the granting and withdrawing of uniform asylum or subsidiary protection status'. On the one hand, E. Tsourdi believes a EU-level processing scenario, in which decisions would be made entirely by a EU authority instead of the Member States, to be legally impossible under article $78(2)$ (e) TFEU, which envisages that 'a Member State' is ultimately responsible for the examination of an application'. ${ }^{23}$ On the other hand, the 2013 Commission's study on the feasibility of joint processing of asy lum applications in the EU considered that article $78(2)$ TFEU, read together with articles $78(1)$ and 80 TFEU, represent an adequate legal basis and open up the possibility for a completely harmonized, EU-based approach for the joint processing of asylum applications within the EU. ${ }^{21}$

\section{(E) COXCLUSIO)}

In spite of the pretentious character of the new name of E ASO, its original core mission remains unchanged. The Member States do not see their enforcement, decision-making, and coercive prerogatives as limited, since this agency's operational powers have only been strengthened and provided with a novel supervisory and monitoring role to ensure the effective functioning of the CE AS. That is, although the European Commission keeps referring to a fully-fledged agency for asylum matters in the EU, the future EU 1 I will neither be conferred decision-making powers regarding asylum applications, nor execulive or enforcement lasks on the ground. The future EUA I will rather be given an assisting role in the examination of applications of international protection by Member States. The EU A I will be far from processing and deciding asy lum applications made in the EU. Instead, the future Regulation on the EU A 1

\footnotetext{
20 European Ombudsman, 'Decision in case 735 2017 MIDC on the European Asslum Support Office's' (E ASO) involvement in the decision-making process concerning admissibility of applications for international protection submilted in the Greek Ilotspots, in particular shortcomings in admissibility interviews', 0.7.07.2018.

${ }^{21}$ Commission, 'Towards a Reform of the Common European Asylum System and Enhancing Legal Avenues to Europe’, COM(2016) 197 linal, o6.o/4.2016, 9 .

${ }_{22}$ Commission, 'A European Agenda on Migration', COM (2015) 2/4o final, 13.5.201 5 .

23 Tsourdi, supra n. I9, at IoI2.

24 Commission, 'Study on the Feasibility and legal and practical implications of establishing a mechanism for the joint processing of asy lum applications on the territory of the EU, $13.02 .2013,75$.
} 
opts for reinforcing the operational tasks of the agency and maintaining the Member States as the exclusive decision-making authorities. 